\title{
Nekros - książka o życiu
}

Jacek Leociak

TEKSTY DRUGIE 2018, NR 4, S. 210-217

DOI: $10.18318 /$ td.2018.4.13

$\mathbf{R}$ efleksja nad śmiercią i umieraniem jest jednym z fundamentalnych tematów humanistyki, filozofii i teologii, medycyny, nauk przyrodniczych. Liczba prac z tej dziedziny jest olbrzymia i trudna do ogarnięcia. Wystarczy spojrzeć tylko na specjalistyczne wydawnictwa bibliograficzne, by zdać sobie sprawę z rozległości tej dziedziny wiedzy. Z górą pół tysiąca stron liczy opublikowana ponad ćwierć wieku temu bibliografia Samuela Southarda Death and Dying. A Bibliographical Survey (Greenwood Press, New York 1991), a przecież przyrost wiedzy i publikacji przez ten czas był skokowy. Nowsza bibliografia Johna Szabo Death and Dying. An Annotated Bibliography of the Thanatological Literature (Scarecrow Press, Lanham 2010) obejmuje okres od 1930 do 2008 roku i w 33 tematycznych rozdziałach odnotowuje 2200 pozycji bibliograficznych. Tanatologia jako dyscyplina naukowa doczekała się nie tylko ogromnej literatury przedmiotu, lecz także podręczników i encyklopedii, np. Encyclopedia of Death and the Human Experience, zredagowana przez Cliftona D. Bryanto i Dennisa L. Pecka (Sage, Los Angeles 2009). Pierwsze czasopismo naukowe poświęcone wyłącznie tematyce tanatologicznej, czyli „Omega - Journal of Death and Dying", zaczęło się ukazywać w 1970 roku
Jacek Leociak - prof. dr hab., kierownik Zakładu Badań nad Literaturą Zagłady IBL PAN, członek-założyciel Centrum Badań nad Zagładą Żydów przy IFiS PAN, redaktor rocznika "Zagłada Żydów. Studia i Materiały". Opublikował ostatnio: m.in: Doświadczenia graniczne. Studia o dwudziestowiecznych formach reprezentacji, Biografie ulic. Ożydowskich ulicach od narodzin po Zagłade, Młyny boże. Zapiski o Kościele iZagładzie. 
w wydawnictwie Sage i wychodzi do dziś. To samo wydawnictwo uruchomiło w 1985 roku „Death Studies”, ukazujące się 10 razy w roku. Warto zaznaczyć, że od 1997 roku Wrocławskie Towarzystwo Naukowe skupia grono badaczy wydających pod kierunkiem Jacka Kolbuszewskiego almanach „Problemy współczesnej tanatologii”. Ukazało się dotychczas piętnaście opasłych tomów, gromadzących artykuły o bardzo szerokim spektrum: od literaturoznawstwa przez filozofię czy religioznawstwo do medycyny.

Dowodem na popularność dyscypliny są antologie o tematyce tanatologicznej. Wskażmy tylko te, które funkcjonują w obszarze języka polskiego. Jeśli chodzi o literaturę francuskojęzyczną - polski czytelnik dysponuje dwiema antologiami przekładów: opracowana przez Stanisława Cichowicza i Jakuba M. Godzimirskiego Antropologia śmierci. Myśl francuska (PWN, Warszawa 1993) oraz Stanisława Rośka Wymiary śmierci (słowo/obraz/terytoria, Gdańsk 2002), przełożone też zostały klasyczne dzieła Phillipe’a Ariesa, Luisa V.Thomasa, Michela Vovelle, Vladimira Jankelevitcha, Jean Baudrillarda. Najnowsza antologia pod redakcją Anny E. Kubiak i Małgorzaty Zawiły Społeczne i kulturowe reprezentacje śmierci. Antologia tekstów ukazała się w 2015 roku w wydawnictwie NOMOS i jest prezentacją literatury przedmiotu powstałej w kręgu języka angielskiego w ostatnich dwóch dekadach. Podzielona na siedem rozdziałów, obejmuje kluczowe problemy współczesnej tanatologii: 1. śmierć w przestrzeni publicznej (ze szczególnym uwzględnieniem polityki i mediów); 2 . współczesne rytuały śmierci (m.in. problematyka kremacji i innych popularnych współcześnie form rozporządzania ciałem); 3. formy żałoby i pamięci (zwłaszcza tendencje do zindywidualizowanego i sprywatyzowanego charakteru odprawiania żałoby); 4 . śmierć - religia - duchowość (m.in. zjawisko sekularyzacji śmierci); 5. kontekst instytucjonalny/profesjonalny śmierci i umierania (zwracający uwagę nie tylko na specyfikę zawodów związanych z „obsługą" umierania i martwego ciała, lecz także na profesjonalizowanie się dyskursów z tego obszaru i ich oddziaływanie społeczne); 6. kulturowe wymiary śmierci (pokazujące obecność śmierci zarówno we współczesnej kulturze Zachodu, również w kulturze popularnej, jak i funeralną obrzędowość Japonii czy Meksyku); 7. kulturowe reprezentacje ciała (prezentujące teksty związane ze studiami nad ciałem chorującym, umierającym i martwym). Rodzime badania związane z tradycyjnie pojętą problematyką tanatologiczną (fenomen śmierci i umierania, rytuały pogrzebowe i żałoba, antropologia, historia i socjologia śmierci czy też archeologia funeralna lub sądowa), wpisują się w domenę antropologii kultury i łączą perspektywę socjologiczną, historyczną, filozoficzną i psychologiczną. Redaktorki wspominanej antologii prezentują we wprowadzeniu podstawowy zarys stanu badań. 
Od lat 9o. ubiegłego wieku w humanistyce żywiołowo rozwijają się studia nad martwym ciałem (dead body studies). Nie należy bowiem utożsamiać tanatologii (czyli death studies), z dead body studies - koncentrujących się nie tyle na samym zjawisku śmierci, ile na „produkcie śmierci”, czyli martwym ciele, problematyzowanym w kategoriach silnie obecnego w nowej humanistyce zwrotu ku materialności, ku rzeczom, a także rozpatrywanym z perspektywy ekologiczno-nekrologicznej. W tym kierunku zmierzają prace Stanisława Rośka - autora studium Zwłoki Mickiewicza. Próba nekrografii poety (1997) i książki będącej kontynuacją tych dociekań Mickiewicz (po śmierci). Studia i szkice nekrograficzne (2013), a jednocześnie redaktora wspomnianej antologii Wymiary śmierci; Anny Wieczorkiewicz - zajmującej się m.in. muzealizacją szczątków ludzkich (Muzeum ludzkich ciał. Anatomia spojrzenia, 2000); Magdaleny Gajewskiej z jej monograficznym opracowaniem Prochy $i$ diamenty. Kremacja ciała zmartego człowieka jako zjawisko społeczne i kulturowe (2009). W tym także kierunku idą - inspirowane zresztą przez Ewę Domańską - badania Marty Zawodnej nad statusem istnienia i strategiami upamiętniania szczątków ludzkich na terenie KL Auschwitz-Birkenau'. Badania Romy Sendyki wraz z jej zespołem nad nieupamiętnionymi miejscami ludobójstwa i statusem istniejących tam ludzkich szczątków, prowadzone są z perspektywy humanistyki forensycznej i środowiskowej historii Holokaustu, a zmierzają do naszkicowania swoistej „mikro-nekro-topografii”. Podejście ekokrytyczne do badań nad Zagładą, uprawianych w ramach antropologii literatury, można dostrzec w pracach Aleksandry Ubertowskiej, która śledzi relacje między ludobójstwem i ekobójstwem, posługując się pojęciem ekocydu ${ }^{3}$.

1 M. Zawodna Wokół tego, co pozostało: biograficzne podejście do badań nad szczątkami ludzkimi na przykładzie włosów eksponowanych w Muzeum Auschwitz-Birkenau, "Kultura i Społeczeństwo" 2007 nr 2; M. Zawodna O porządkowaniu świata poobozowego. Sposoby postępowania ze szczq̨tkami ludzkimi na terenach byłego obozu KL Auschwitz-Birkenau od momentu ostatecznej likwidacji do powstania muzeum, „Zagłada Żydów. Studia i Materiały” $2012 \mathrm{nr} 8$.

2 W ramach prowadzonego przez Romę Sendykę projektu badawczego "Nieupamiętnione miejsca ludobójstwa i ich wpływ na pamięć zbiorową, tożsamość kulturową postawy etyczne i relacje międzykulturowe we współczesnej Polsce" finansowanego w ramach "Narodowego Programu Rozwoju Humanistyki" (Nr 121/NPRH4/H2a/83/2016) przygotowana została publikacja Nie-miejsca i ich nie-pamięć. Por. R. Sendyka Robinson w nie-miejscach pamięci , "Konteksty”. Polska Sztuka Ludowa. Antropologia Kultury. Etnografia. Sztuka R. LXVIII (2013) nr 2 (301).

3 A. Ubertowska Natura u kresu (ekocyd). Podmiotowość po katastrofie, "Teksty Drugie" 2013 nr 1/2; A. Ubertowska Holokaust. Auto(tanato)grafie, Wydawnictwo IBL PAN, Warszawa 2014. 


\section{**⿻}

W zarysowanym tu pobieżnie kontekście rodzimych badań dokonania Ewy Domańskiej są bezprecedensowe i pionierskie, nie dają się z niczym na polskim gruncie porównać. To właśnie Ewa Domańska postuluje wyraźne rozgraniczenie death studies (tanatologii) od dead body studies (studia nad martwym ciałem i szczątkami). W swojej książce pisze: „Proponuję studia martwego ciała i szczątków jako samodzielne i wielodziedzinowe pole badań, dystansując je od tanatologii o tyle, o ile sama nazwa "tanatologia” sugeruje badanie szeroko rozumianych zjawisk i procesów związanych ze śmiercią, podczas gdy proponowane tutaj podejście do badania martwego ciała i szczątków przynależy do wiedzy i nauk o życiu, gdzie śmierć uznawana jest jako jedno z wydarzeń (fundujących) procesy życiowe"4. Autorka uzasadnia dynamiczny rozwój dead body studies jako osobnej dziedziny badań, przytaczając splot dziewięciu powodów obejmujących szerokie spektrum: od życia politycznego i społecznego, przez zagadnienia medyczne, kryminalistyczne i etyczne dotyczące obchodzenia się ze szczątkami ludzkimi, politykę pamięci po kwestie kurczenia się miejsc przeznaczanych na cmentarze i problematykę ekologiczną.

Pada tutaj bardzo ważne zastrzeżenie, znamionujące charakterystyczną dla całej książki dbałość o klarowność wywodu oraz last but not least - dążność do zamanifestowania własnej postawy badawczo-etycznej (problematyka etyki badań naukowych i moralnych zobowiązań badaczy znalazła wyraz m.in. w książce Domańskiej Historia egzystencjalna. Krytyczne studium narratywizmu i humanistyki zaangażowanej (PWN, Warszawa 2012) oraz w niektórych jej artykułach i wywiadach). Otóż autorka stwierdza dobitnie: „Zainteresowania martwymi ciałami, kośćmi i prochami dla wielu mogą się wydać przejawem patologii i rodzajem badawczej nekrofilii"s. Oddalając takie podejrzenia, Ewa Domańska przytacza „rozbudowaną argumentację przemawiającą za zasadnością podejmowania takich badań. Nie chodzi tu bowiem tylko o poruszanie tematów pomijanych. W takiej perspektywie, kwestia postępowania z martwymi ciałami byłaby tylko jeszcze jednym ciekawym i nieprzebadanym problemem. Nie chodzi jednak o mnożenie kolejnych pól zainteresowań badawczych o badania martwych ciał i szczątków (także martwych zwierząt czy roślin). Istotna jest natomiast oferowana przez podejścia nieantropocentryczne odmienna rama teoretyczna, która prowokuje inne pytania badawcze,

\footnotetext{
4 E. Domańska Nekros. Wprowadzenie do ontologii martwego ciała, PWN, Warszawa 2017, s. 18.

5 Tamże, s. 21.
} 
oferuje odmienne interpretacje, inspiruje do zastosowania lub wprowadzenia innych/nowych podejść, teorii i metod, ukazując w innym świetle problemy znane, a uwidaczniając te, które przez humanistów były dotychczas niedostrzegane, ignorowanie, pomijane lub marginalizowane"6.

Ewa Domańska od wielu lat w swych pracach podejmuje m.in. zagadnienia archeontologii martwego ciała, nekropolityki historycznej, bada z perspektywy forensycznej ekshumację i szczątki ofiar w Jedwabnym, zastanawia się nad semiotycznym i ontologicznym statusem śladów po ofiarach bomby atomowej w Hiroszimie czy, wreszcie - fenomen szczątków ludzkich przekształconych w węglową postać LifeGem, czyli tzw. diamentów pamięci. Nekrotyczne wątki obecne były od dawna w jej pracach (by wspomnieć studium o świadectwie dotyczącym kanibalizmu w gułagu, traktowanym jako egzystencjalny ślad transhumacji ${ }^{7}$, czy poruszające studium o argentyńskich desaparecidos - nigdy nieodnalezionych ofiarach junty wojskowej w Argentynie ${ }^{8}$ ). Nekros. Wprowadzenie do ontologii martwego ciała stanowi summę prowadzonych systematycznie od lat dociekań. Co więcej - Nekros jest nie tylko pierwszym w polskiej literaturze przedmiotu monograficznym ujęciem zagadnień z wielonurtowego pola dead body studies, wyrosłym na imponującej erudycji i zaznajamiającym polskiego czytelnika z ogromem najnowszych prac światowej literatury przedmiotu. Nekros jest oryginalnym autorskim projektem badawczym, więcej - głęboko przemyślanym i precyzyjnie skonstruowanym swego rodzaju manifestem humanistycznym, proklamacją humanistyki zaangażowanej, ratowniczej, prefiguratywnej, niosącej postulat sprawiedliwości epistemicznej i wzywającej do „epistemicznego nieposłuszeństwa”. Domańska wielokrotnie pisała już o potrzebie przezwyciężenia wciąż dominującego dyskursu traumy na rzecz budowania trudnej nadziei i humanistyki performatywnej, aktywnie prefigurującej przyszłość, a nie kontemplacyjnie zatapiającej się w demonach przeszłości. Projekt Ewy Domańskiej, którego książka Nekros jest najpełniejszą prezentacją, jest zawieszony między utopią i wizją, zakorzeniając się jednocześnie w holistycznie i transdycyplinarnie pojętej nauce. I to jest w tej książce prawdziwie fascynujące! W tym właśnie upatrywałbym jej największą wartość. Przekracza

6 Tamże, s. 22.

7 E. Domańska Hermeneutyka przejścia. Wspomnienia z Rosji Jana Żarno, w: tejże Historie niekonwencjonalne. Refleksie o przeszłości w nowej humanistyce, Wydawnictwo Poznańskie, Poznań 2006.

8 Archeontologia martwego ciała. Argentyńscy desaparecidos, w: tamże. 
ona tradycyjną formułę „zbioru studiów” (nawet najbardziej interesujących i poznawczo nowatorskich), a staje się ważną, żarliwą, osobistą wypowiedzią o kondycji współczesnej humanistyki, jej zmaganiach ze światem i jej perspektywach na przyszłość. Książki o takim potencjale prospektywnym, takim epistemologicznym i etycznym zaangażowaniu zdarzają się bardzo rzadko.

Fundamentem wykładanej przez Ewę Domańską ontologii martwego ciała są pytania: „czym jest życie i jaka jest jego przyszłość, czym/kim jest człowiek, jak ludzie współtworzą życie na Ziemi, jakie są mechanizmy istnienia wielogatunkowych wspólnot/zbiorowisk"'. Tak zakreśla autorka horyzont poznawczy swoich dociekań i stawia hipotezę, rewolucjonizującą dotychczasowe refleksje nad martwym ciałem prowadzone na obszarze polskiej humanistyki. Wyłania się z niej podstawowa figura tej książki - „Nekros”. Warto zacytować obszerniejsze fragmenty wywodu. Pozwalam sobie tu na przytoczenie dłuższego cytatu nie tylko z powodu jego merytorycznej doniosłości i stopnia kondensacji podstawowych założeń teoretyczno-metodologicznych. Jest on również dobrym przykładem gęstości języka i jego nasycenia terminologią, co stanowi dla czytelnika nie lada wyzwanie. W przypadku tekstów Ewy Domańskiej podjęcie takiego wyzwania stokrotnie się opłaca:

Martwe ludzkie ciało i szczątki są ważne i wartościowe nie tyle ze względu na osobę, której stanowią pozostałość, czy ze względu na to, co można z nich zrobić (np. diament pamięci, dzieło sztuki, plastynat, relikwie), lub do czego je można wykorzystać w sensie symbolicznym i materialnym (np. polityka historyczna, rytuały religijne, a także transplantacje, materiał genetyczny, autopsje, eksperymenty medyczne). Dla prowadzonych tutaj rozważań najważniejsze staje się to, że w perspektywie bardzo długiego trwania (deep history), która jest tutaj zasadnicza, w sensie organicznym (skład pierwiastkowy), szczątki są nekroindykatorami człowieka - formy życia opartej na węglu i wskazują na jego zamieszkiwanie na Ziemi poprzez swój rozkład wpływając na skład chemiczny ziemi, wody i powietrza. [...] W tym sensie rozkładające się ciało, szczątki, kości, prochy są rodzajem osoby (persony) - często zbiorowej - i mogą być uważane za sprawców (agents). Można zatem powiedzieć, że złożenie szczątków do ziemi (ciała lub prochów) „humanizuje” ją, lecz w proponowanym tu ujęciu przez humanizację rozumiem proces mieszania się dekomponujących się szczątków z innym materiałem organicznym 
i nieorganicznym, co dzieje się m.in. w procesie humifikacji i mineralizacji (butwienie, gnicie) w wyniku których powstaje specyficzna forma istnienia Nekrosu - humus (nekrobiont), który uznaję tutaj za rodzaj materialnej prazasady, macierzy, podstawy. [...] Nekros manifestuje życie nieodłączne od materii; życie jako rodzaj związku [wyróż. - J.L.]. To zarówno realny, materialny i dynamiczny byt, jak i proces stałego przekształcania się wskazujący nieograniczony potencjał do zmian, a przede wszystkim przemian. Nekros jest wielopostaciowy. Jest bytem w sensie podstawy, podłoża i jako taki jest metapodmiotem, symbiotycznym holobiontem (czy nekrobiontem), rodzajem metawspólnoty (metacommunity)). Ma różne wcielenia stających się bytów, przybierając formę neomorta, rozkładającego się ciała, kości, prochów, popiołów, a także rośliny czy kryształu. [...] Przy takim rozumieniu Nekrosa, proponowane tutaj ujęcie lokuje się w ontologii zarówno stawania się, jak i substancjalnego bycia. W takim czy innym wcieleniu, Nekros zawsze jednak symbolizuje przenikanie się i przekraczanie tego, co ludzkie i nie-ludzkie, organiczne i nieorganiczne, a przede wszystkim tego, co żywe i martwe [wyróż. - J.L]. ${ }^{10}$

Konstatacja, że „bycie-ku-martwemu-ciału pomaga zrozumieć stawanie-się-życia"11, konstytuuje postawę poznawczą, którą Ewa Domańska nazywa "materializmem ekologicznym” (czy „ekomaterializmem”). Chodzi tu, po pierwsze - o założenie dotyczące „pierwotności materii ujmowanej przez pryzmat relacji, związków, zależności panujących między współtworzącymi ją organicznymi i nieorganicznymi elementami” oraz po drugie - o „nekrowitalizm, tj. ide[ę] powstawania życia z materii martwej, a także czerpania sił życiowych i zasobów potrzebnych do życia, z tego, co martwe"12. Ontologia martwego ciała i szczątków ujęta jest w tej książce jako pewien system teoretyczny, na który składają się: 1) kategoria nekropersony, 2) kategoria nekrosprawczości, 3) koncepcja nekrowitalizmu, 4) koncepcja materializmu ekologicznego, oraz 5) pojęcie nekroetyki szacunku i wzajemności. Podkreślam raz jeszcze, że cała ta konstrukcja myślowa, brzmiąca może nazbyt zimno, abstrakcyjnie, scjentystycznie i bezdusznie, zbudowana jest na głębokich podstawach etycznych i wyrosła z etycznych i duchowych motywacji czy - jak

Tamże, s. 66-67, 68.

Tamże, s. 70. 
określa to autorka - z poczucia „etycznego dyskomfortu” w obliczu rozpowszechniających się praktyk politycznego i medycznego wykorzystywania ludzkich szczątków oraz ze świadomości zagrożeń, jakie niesie ze sobą technologiczne przyspieszanie dekompozycji i utylizacji zwłok. Swoją postawę szacunku dla martwego ciała w jego naturalnym trwaniu i swoje zatroskanie nazywa Ewa Domańska „nekroetyką szacunku i współbycia"13 między żywymi i umarłymi. Ten postulat etyczny ma również swoją wielką siłę epistemiczną - co jest znamienną cechą całego dyskursu prowadzonego w recenzowanej książce. Ewa Domańska potrafi połączyć w całość to, co należy do sfery poznania i to, co jest domeną postaw etycznych, a także to, co przekształca jej projekt badawczy w manifest humanistyczny.

Książkę Ewy Domańskiej uważam za jedno z najwybitniejszych dzieł naukowych ostatnich lat. Jego wartość polega nie tylko na zdefiniowaniu nowej problematyki i zastosowaniu nowoczesnej transdyscyplinarnej metodologii do jej zbadania, nie tylko na odkrywczych i inspirujących interpretacjach. Stanowi ona rodzaj manifestu nowej humanistyki, zatroskanej o stan świata, zaangażowanej w rozpoznanie kondycji ludzkiej i budowanie nadziei, otwierającej dla człowieka perspektywy na przyszłość pojętą w kategoriach planetarnych, ekologicznych, wspólnotowych.

\section{Abstract}

\section{Jacek Leociak}

THE INSTITUTE OF LITERARY RESEARCH OF THE POLISH ACADEMY OF SCIENCES (WARSAW) Nekros - A Book about Life

Review: Ewa Domańska, Nekros: Wprowadzenie do ontologii martwego ciała [Necros: An Introduction to the Ontology of the Dead Body] (Warsaw: Wydawnictwo Naukowe PWN, 2017).

\section{Keywords}

new humanities, biohumanities, dead body studies, necropolitics, forensic turn, ecocriticism, Holocaust

13 Tamże, s. 72. 